\title{
NOTARIS DAN PENEMUAN HUKUM
}

\author{
Ishaq \\ Fakultas Syari'ah IAIN STS Jambi
}

\begin{abstract}
Abstrak
Artikel ini menjelaskan konsep notaris sebagai profesi hukum dalam menemukan hukum. Notaris dalam melakukan proses penemuan hukum bersifat problematis yang artinya masalah-masalah yang diajukan oleh klien, di mana hasilnya merupakan hukum, tetapi belum dapat dikatakan sebagai sumber hukum, sebab belum ada satupun dalam teori yang mengemukakan tentang Notaris merupakan sumber hukum dalam menemukan hukum.
\end{abstract}

Kata kunci: notaris, profesi hukum, penemuan hukum

\begin{abstract}
This article describes the concept of a notary public as the law of the legal profession. Notary in the process of legal discovery are problematic, which means the problems posed by the client, where the result is legal but can not be considered as a source of law, because there is no one theory that suggests about the notary is a source of law in finding the law.
\end{abstract}

Keyword: notaris, the legal profession, legal invention

\section{Pendahuluan}

Salah satu sistem hukum ${ }^{1}$ yang berlaku di Indonesia adalah sistem hukum Barat, yakni sistem hukum Eropa Kontinental (civil law). Sistem ini diperkenalkan di Indonesia

\footnotetext{
${ }^{1}$ Sistem hukum merupakan susunan sebagai satu kesatuan yang tersusun dari sejumlah bagian-bagian yang dinamakan subsistem hukum, yang secara bersama-sama mewujudkan kesatuan yang utuh. Keberadaan sistem hukum Indonesia misalnya, maka dalam sistem hukum positifnya terdiri atas subsistem hukum pidana, subsistem hukum perdata, subsistem hukum tata negara, tentu saja saling berbeda tetapi tetap dalam satu kesatuan, yaitu sistem hukum Indonesia. Marwan Mas, 2004, Pengantar Ilmu Hukum, Ghalia Indonesia, Jakarta, hlm, 100. Kemudian Sudikno Mertokusumo menjelaskan bahwa sistem hukum adalah kesatuan utuh dari tatanan-tatanan yang terdiri atas bagian-bagian atau unsur-unsur yang satu sama lain saling berhubungan dan kait-mengkait secara erat. Dengan demikian, untuk mencapai tujuan hukum dalam satu kesatuan, diperlukan kesatuan sinergi antara unsur-unsur yang terkandung di dalam sistem hukum, seperti peraturan, peradilan, pelaksana hukum, dan partisipasi warga masyarakat. Sistem hukum bukan sekedar kumpulan peraturan hukum, melainkan setiap peraturan itu saling berkaitan satu dengan yang lainnya, seperti tidak boleh terjadi konflik atau kontradiksi di dalamnya. Sudikno Mertokusumo, Mengenal Hukum Suatu Pengantar, Liberty, Yogyakarta, 1999, hal. 116. Lebih lanjut Lawrence M. Friedman menjelaskan, bahwa sistem hukum itu mempunyai tiga unsur (three elements of legal sistem). Ketiga unsur sistem hukum tersebut adalah struktur (structure), substansi (substance) dan kultur hukum (legal culture). Struktur diartikan sebagai kerangka atau rangkanya, bagian yang tetap bertahan, bagian yang memberikan semacam bentuk dan batasan terhadap keseluruhan. Substansi diartikan sebagai aturan, norma, dan pola perilakunyata manusia yang berada dalam sistem itu. Kultur hukum diartikan sebagai sikap manusia terhadap hukum, kepercayaan, nilai, pemikiran, serta harapannya.
} 
bersamaan dengan kedatangan orang-orang Belanda untuk berdagang di Indonesia. Mula-mula hanya diperlakukan bagi orang Belanda dan Eropa saja, tetapi kemudian melalui berbagai upaya peraturan perundang-undangan, yakni penundukan dengan sukarela, dan pilihan hukum, hukum Barat itu dinyatakan berlaku juga bagi mereka yang disamakan dengan orang Eropa, orang Timur Asing, terutama orang Cina dan orang Indonesia. Sebagai hukum bagi golongan yang berkuasa pada waktu itu di nusantara ini keadaan hukum Barat jauh lebih baik dan menguntungkan dari keadaan kedua sistem hukum tersebut, yakni hukum adat dan hukum Islam bagi pemerintah kolonial Belanda.

Karakteristik sistem hukum civil law ditandai dengan adanya suatu kodifikasi atau pembukuan hukum atau undang-undang dalam suatu kitab (code). Dalam suatu kodifikasi dihimpun sebanyak-banyaknya ketentun-ketentuan hukum yang sisusun secara sistematis. ${ }^{2}$ Hukum pada umumnya merupakan suatu peraturan perundangundangan, terutama bagi kalangan praktisi.

Undang-undang itu kurang sempurna, dan tidak mungkin undang-undang itu mengatur segala kegiatan kehidupan manusia secara tuntas. Ada kalanya undangundang itu tidak lengkap dan ada kalanya undang-undang itu tidak jelas. Meskipun tidak lengkap atau tidak jelas undang-undang harus dilaksanakan. ${ }^{3}$ Peraturan perundang-undangan dilaksanakan bertujuan untuk mengatur kegiatan kehidupan manusia. Kegiatan kehidupan manusia itu sedemikian luasnya, sehingga tidak terhitung lagi jenis dan jumlahnya. Dengan demikian menurut Sudikno Mertokusumo, tidak mungkin satu peraturan perundang-undangan mengatur seluruh kegiatan kehidupan manusia. ${ }^{4}$ Oleh karena itu perlu dicari hukumnya, harus menemukan hukumnya.

Notaris sebagaimana disebutkan di dalam Pasal 1 ayat (1) Undang-undang Republik Indonesia Nomor 2 Tahun 2014 tentang Perubahan Atas Undang-undang Nomor 30 Tahun 2004 tentang Jabatan Notaris disebutkan bahwa Notaris adalah pejabat umum yang berwenang untuk membuat akta autentik dan memiliki kewenangan

Lawrence M. Friedman, Sistem Hukum Perspektif Ilmu Sosial, terj. oleh M. Khozim, Nusa Media, Bandung, cetakan keempat, 2011, hal. 15-17.

${ }^{2}$ Ahmad Rifai, 2011, Penemuan Hukum oleh Hakim Dalam Persfektif Hukum Progresif, Sinar Grafika, Jakarta, hal. 17.

${ }^{3}$ Sudikno Mertokusumo \& A. Pitlo, Bab-Bab Tentang Penemuan Hukum, Citra Aditya Bakti, Bandung, 2013, hal. 3.

${ }^{4}$ Sudikno Mertokusumo, Penemuan Hukum Sebuah Pengantar, Cahaya Atma Pustaka, Yogyakarta, 2014, hal. 63. 
lainnya sebagaimana dimaksud dalam Undang-undang ini atau berdasarkan undangundang lainnya. ${ }^{5}$

Perkembangan hukum yang sangat cepat tentu mempengaruhi tugas yang dijalankan oleh notaris untuk membuat akta-akta dalam rangka mengikuti perkembangan atau perbuatan manusia yang begitu cepat tersebut. Dengan begitu cepatnya perkembangan hukum di masyarakat maka notaris dituntut dapat menemukan cara atau terobosan untuk memenuhi kebutuhan masyarakat tersebut seperti apa yang ada dalam Undang-Undang, kegiatan tersebut disebut Penemuan Hukum yang lazimnya diartikan sebagai pembentukan hukum oleh hakim atau petugas-petugas hukum lainnya yang diberi tugas melaksanakan hukum terhadap peristiwa-peristiwa hukum yang konkrit. ${ }^{6}$

Berdasarkan dari penjelasan tersebut di atas, kiranya menarik untuk mengkaji tentang penemuan hukum oleh notaris yang lazimnya dikenal profesi yang paling banyak melakukan penemuan hukum adalah hakim, karena setiap harinya hakim dihadapkan pada peristiwa konkrit atau konflik yang harus diselesaikan. Hakim menemukan hukum itu bersifat konfliktif. Adapun permasalahan dalam makalah ini adalah bagaimanakah sifat penemuan hukum oleh notaris?

Untuk menjawab permasalahan tersebut, penulis menggunakan metode deskriptif analisis berusaha memaparkan data-data secara akurat tentang pendapat para ahli hukum. Kemudian akan dilakukan suatu analisis secara mendalam, sehingga diharapkan dapat ditemukan suatu jawaban yang komprehensif. Pengumpulan data dilakukan secara library research, dengan mempelajari dari buku-buku penemuan hukum, undang-undang Notaris, serta tulisan ilmiah lainnya yang berkaitan dengan pokok masalah.

\section{Pembahasan}

\section{Istilah dan Pengertian Penemuan Hukum}

Istilah penemuan hukum di dalam praktik di pengadilan sering diperbandingkan dengan beberapa istilah yaitu istilah pelaksanaan hukum, penerapan hukum, pembentukan

\footnotetext{
${ }^{5}$ Undang-Undang Republik Indonesia Nomor 2 Tahun 2014 tentang Perubahan Atas Undang-undang Nomor 30 Tahun 2004 tentang Jabatan Notaris, Pustaka Mahardika, Yogyakarta, hal. 4.

${ }^{6}$ Mulyono, "Peranan Penemuan Hukum oleh Notaris Berkaitan dengan Pembuatan Akata-akta Penjualan Jaminan Kredit Macet yang Dijamin dengan Hak Tanggungan”, http://mulyonotaris.blogspot.co.id/2014/ 06/peran-penemuan-hukum-oleh-notaris.html, diakses 11 September 2015.
} 
hukum, atau penciptaan hukum. Akan tetapi masing-masing istilah tersebut tidaklah sama karena mempunyai perbedaan-perbedaan.

Adapun pengertian masing-masing istilah tersebut menurut Sudikno Mertokusumo adalah sebagai berikut:

1. Pelaksanaan hukum dapat berarti menjalankan hukum tanpa adanya sengketa atau pelanggaran.Ini meliputi pelaksanaan hukum oleh setiap warga negara setiap hari yang sering tidak disadarinya dan juga oleh aparat negara, seperti seorang polisi yang berdiri di perempatan jalan mengatur lalu lintas (law enforcement). Di samping itu, pelaksanaan hukum dapat terjadi kalau ada sengketa, yaitu yang dilaksanakan oleh hakim. Ini sekaligus merupakan penegakan hukum

2. Penerapan hukum, berarti menerapkan (perturan) hukum yang abstrak sifatnya pada peristiwanya. Menerapkan (peraturan) hukum pada peristiwa konkret secara langsung tidak mungkin. Peristiwa konkret itu harus dijadikan peristiwa hukum terlebih dahulu agar peraturan hukumnya dapat diterapkan. Di waktu yang lampau dikatakan bahwa hakim adalah corong undang-undang, karena kewajibannya hanyalah menerapkan undang-undang, ia adalah subsumtie automaat.

3. Pembentukan hukum, adalah merumuskan peraturan-peraturan umum yang berlaku umum, bagi setiap orang. Lazimnya pembentukan hukum dilakukan oleh pembentuk undang-undang, hakim dimungkinkan pula membentuk hukum, kalau hasil penemuan hukumnya itu kemudian merupakan yurisprudensi tetap yang diikuti oleh para hakim dan merupakan pedoman bagi masyarakat, yaitu putusan yang mengandung asas-asas hukum yang dirumuskan dalam peristiwa kongkret, tapi memperoleh kekuatan berlaku umum. Jadi satu putusan dapat sekaligus mengandung dua unsur, yaitu disatu pihak putusan merupakan penyelesaian atau pemecahan suatu peristiwa konkret dan di pihak lain merupakan peraturan hukum untuk waktu mendatang.

4. Penciptaan hukum, merupakan istilah kurang tepat,karena memberi kesan bahwa hukumnya itu sama sekali tidak ada, kemudian diciptakan: dari tidak ada menjadi ada. Hukum bukanlah selalu berupa kaidah baik tertulis maupun tidak, tetapi dapat juga berupa perilaku atau peristiwa. Di dalam perilaku itulah terdapat hukumnya. Dari perilaku itulah harus diketemukan atau digali kaidah atau hukumnya (lihat pasal 5 (1) Undang-Undang Nomor 48 Tahun 2009). ${ }^{7}$

Dalam perkembangan selanjutnya istilah penemuan hukum dan pembentukan hukum saling bercampur baur, akan tetapi kedua istilah tersebut pada hakekatnya sama sama menunjuk pada suatu kondisi yang belum terdapat peraturan umum yang mendasarinya atau sudah ada, namun demikian peraturan tersebut kurang jelas, sehingga diperlukan suatu penemuan hukum atau pembentukan hukum yang dilakukan oleh hakim.

\footnotetext{
${ }^{7}$ Sudikno Mertokusumo, Op.Cit, hal. 47-48.
} 
Istilah penemuan hukum sering dipergunakan oleh hakim, sedangkan pembentukan hukum itu sering digunakan oleh lembaga pembentuk undang-undang. Selanjutnya Utrecht berpendapat, bahwa penemuan hukum itu adalah hal suatu peraturan perundang-undangan belum jelas atau belum mengaturnya, hakim harus bertindak berdasarkan inisiatifnya sendiri untuk menyelesaikan perkara tersebut. ${ }^{8}$

Adapun pengertian penemuan hukum menurut Sudikno Mertokusumo, dan A Pitlo adalah proses pembentukan hukum oleh hakim atau petugas-petugas hukum lainnya yang diberi tugas melaksanakan hukum terhadap peristiwa-peristiwa hukum yang konkrit. ${ }^{9}$ Kemudian Paul Scholten memberikan suatu penjelasan bahwa hukum merupakan satu sistem, yang berarti semua aturan saling berkaitan, aturan-aturan itu dapat disusun secara mantik, dan untuk yang bersifat khusus dapat dicarikan aturanaturan umumnya, sehingga tiba pada asasnya. Namun tidaklah berartibahwa hakim hanya bekerja secara mantik semata-mata. Hakim juga harus bekerja atas dasar penilaian, dan hasil dari penilaian itu menciptakan sesuatu yang baru. ${ }^{10}$

Lebih lanjut dijelaskan oleh Loudoe, bahwa penemuan hukum bukan suatu proses yang logis belaka melalui subsumpsi dari fakta pada ketentuan undang-undang, akan tetapi adalah juga penilaian dari fakta untuk kemudian menemukan hukumnya. ${ }^{11}$ Kemudian J.A. Pontier mengemukakan bahwa penemuan hukum adalah sebuah reaksi terhadap situasi problematik yang dipaparkan orang dalam pristilahan hukum. Masih menurut Pointier, peneman hukum diarahkan pada pemberian jawaban atas pertanyaanpertanyaan tentang hukum yang ditimbulkan oleh kejadian-kejadian konkret. ${ }^{12}$

Penemuan hukum dilakukan disebabkan karena undang-undang tidak lengkap dan tidak jelas. Hukum itu tidak hanya ada dalam bentuk peraturan perundangundangan saja, tetapi juga ada pada perilaku manusia. Setiap hari senantiasa berperilaku, maka setiap hari juga sering diadakan hubungan dengan orang lain yang sering tidak disadari bahwa itu merupakan perbuatan atau hubungan hukum. Sebagi contoh, bahwa perjanjian beli sewa tidak diatur dalam Kitab Undang-Undang Hukum Perdata, tetapi merupakan perilaku dua orang yang kemudian dituangkan yurisprudensi

\footnotetext{
${ }^{8}$ Utrecht, Pengantar dalam Hukum Indonesia, Ichtiar, Jakarta, 1983, hal. 248.

${ }^{9}$ Sudikno Mertokusumo \& A. Pitlo, Op.Cit, hal. 4.

${ }^{10}$ Achmad Ali, Menguak Tabir Hukum (Suatu Kajian Filosofis dan Sosiologis), Gunung Agung, Jakarta, 2002, hal. 141.

${ }^{11}$ John Z. Loudoe, Menemukan Hukum Melalui Tafsir Dan Fakta, Bina Aksara, Jakarta, 1985, hal. v.

12 J.A. Pontier, Penemuan Hukum, terj. oleh B. Arief Shidarta, Jendela Mas Pustaka, Bandung, 2008, hal. 1.
} 
menjadi hukum. Di dalam Undang-Undang Nomor 48 Tahun 2009 tentang kekuasaan kehakiman Pasal 5 ayat (1) mengatakan bahwa hakim dan hakim konstitusi wajib menggali, mengikuti, dan memahami nilai-nilai hukum dan rasa keadilan yang hidup dalam masyarakat.

Apa yang dituangkan dalam Pasal tersebut di atas merupakan perintah dari undang-undang dan karenanya ia merupakan kewajiban bagi pengadilan untuk melaksanakannya. Menggali, mengikuti dan memahami nilai-nilai hukum atau apa yang dapat menjadi hukum dan menemukan rasa keadilan yang hidup dalam masyarakat merupakan kewajiban bagi hakim untuk mencarinya dalam suatu ruang, suatu tempat atau suatu keadaan di mana nilai-nilai hukum yang diwajibkan dapat ditemukan. ${ }^{13}$ Penemuan hukum dapat ditemukan dalam hukum itu sendiri sehingga sering dikatakan bahwa hukum sebagai elemen penemuan hukum.

\section{Notaris Sebagai Penemu Hukum}

Notaris merupakan suatu profesi dalam bidang hukum yang memberikan jasa hukum kepada masyarakat berupa akta sebagai alat bukti tertulis yang bersifat autentik tentang perbuatan, perjanjian, penetapan, dan peristiwa hukum yang diharuskan oleh peraturan perundang-undangan yang berlaku. Di dalam Pasal 1 (1) Undang-Undang Republik Indonesia Nomor 2 Tahun 2014 tentang Perubahan Atas Undang-Undang Nomor 30 Tahun 2004 tentang Jabatan Notaris disebutkan bahwa Notaris adalah pejabat umum yang berwenang untuk membuat akta autentik dan memiliki kewenangan lainnya sebagaimana dimaksud dengan Undang-Undang ini atau berdasarkan undang-undang lainnya. $^{14}$

Notaris dalam menjalankan tugasnya memiliki kewenangan dan laranganlarangan sebagaimana dijelaskan di dalam Pasal $15,{ }^{15}$ Pasal $16,{ }^{16}$ dan Pasal 17 Undang-

13 Yudha Bhakti, "Penemuan Hukum Suatu Proses Memahami Ajaran Sumber Hukum", Pidato Purnabakti 70 Tahun, Fakultas Hukum Universitas Padjadjaran, Bandung, 2012, hal. 2.

${ }^{14}$ Pasal 1 (1) Undang-Undang Republik Indonesia Nomor 2 Tahun 2014 tentang Perubahan Atas UndangUndang Nomor 30 Tahun 2004 Tentang Jabatan Notaris, Pustaka Mahardika, Yogyakarta, t.th.

${ }^{15}$ Notaris berwenang membuat Akta autentik mengenai semua perbuatan, perjanjian, dan penetapan yang diharuskan oleh peraturan perundang-undangan dan/atau yang dikehendaki oleh yang berkepentingan untuk dinyatakan dalam Akta autentik, menjamin kepastian tanggal pembuatan Akta, menyimpan Akta, memberikan grosse, salinan dan kutipan Akta, semuanya itu sepanjang pembuatan Akta itu tidak juga ditugaskan atau dikecualikan kepada pejabat lain atau orang lain yang ditetapkanditugaskan atau dikecualikan kepada pejabat lain atau orang lain yang ditetapkan oleh undang-undang.

${ }^{16}$ Notaris dalam menjalankan jabatannya berkewajiban di antaranya bertindak amanah, jujur, saksama, mandiri, tidak berpihak, dan menjaga kepentingan pihak yang terkait dalam perbuatan hukum. Membuat 
undag Notaris, ${ }^{17}$ yakni Undang-undang Republik Indonesia Nomor 2 Tahun 2014 tentang Perubahan Atas Undang-undang Nomor 30 Tahun 2004 tentang Jabatan Notaris.

Penemuan hukum tidak sama dengan penciptaan hukum. Menemukan hukum berarti menemukan hukumnya yang sudah ada. Hal ini dijelaskan oleh Paul Scholten bahwa pada intinya menyatakan bahwa hukum itu ada, tetapi masih harus ditemukan. ${ }^{18}$ Penemuan hukum berbeda dengan penerapan hukum. Di dalam penemuan hukum ditemukan sesuatu yang baru yang dapat dilakukan, baik lewat penafsiran analogi, maupun penghalusan hukum. Penegakan hukum tidak hanya dilakukan dengan logika penerapan hukum yang mengandalkan penggunaan logika, melainkan melibatkan penilian dan memasuki ranah pemberian makna. ${ }^{19}$

Pihak yang dikenal luas dalam sejarah maupun di dalam literatur melakukan penemuan hukum pada umumnya adalah hakim, yakni penemuan hukum konfliktif. Hakim melakukan menemukan hukum. Hal ini tidak mengherankan oleh tugas hakim sehari-hari adalah memecahkan konflik, sengketa atau masalah hukum konkrit. Oleh karena itu hakim harus menemukan hukum.

Di samping hakim yang melakukan penemuan hukum juga Notaris memang bukan hakim yang harus memeriksa dan mengadili perkara, bertugas dalam litigasi Notaris. Di dalam prakteknya, Notaris lebih banyak membuat akta dalam bentuk akta buku yang bentuknya telah ditentukan oleh pemerintah dalam undang-undang, yakni akta-akta autentik pada umumnya, misalnya pada akta hibah, akta inbreng, akta-akta

\footnotetext{
Akta dalam bentuk Minuta Akta dan menyimpangnya sebagai bagian dari Protokol Notaris, meletakkan surat dan dokumen serta sidik jari penghadap pada Minuta Akta; mengeluarkan Grosse Akta, Salinan Akta, atau Kutipan Akta berdasarkan Minuta Akta; memberikan pelayanan sesuai dengan ketentuan dalam Undang-Undang ini, krcuali ada alasan untuk menolaknya; merahasiakan segala sesuatu mengenai Akta yang dibuatnya dan segala keterangan yang diperoleh guna pembuatan Akta sesuai dengan sumpah/janji jabatan, kecuali undang-undang menentukan lain.

17 Notaris dilarang, diantaranya, menjalankan jabatan di luar jabatannya, meninggalkan wilayah jabatannya lebih dari 7 (tujuh) hari kerja berturut-turut tanpa alasan yang sah, merangkap sebagai pegawai negeri, merangkap jabatan sebagai pejabat negara, merangkap jabatan sebagai advokat, merangkap jabatan sebagai pemimpin atau pegawai badan uaha milik negara, badan usaha milik daerah atau badan usaha swasta; merangkap jabatan sebagai Pejabat Pembuat Akta Tanah dan/atau Pejabat Lelang Kelas II di luar tempat kedudukan Notaris;menjadi Notaris Pengganti; melakukan pekerjaan lain yang bertentangan dengan norma agama, kesusilaan, atau kepatutan yang dapat mempengaruhi kehormatan dan martabat jabatan Notaris.

${ }^{18}$ Paul Scholten, dalam Eddy O.S. Hiariej, Asas-Legalitas \& Penemuan Hukum Dalam Hukum Pidana, Erlangga, Jakarta, 2009, hal. 55.

${ }^{19}$ Satjipto Rahardjo, "Penafsiran Hukum Yang Progresif", dalam Anthon Freddy Susanto, Semiotika Hukum: Dari Dekonstruksi Teks Menuju Progresivitas Makna, Refika Aditama, Bandung, 2005, hal. 911.
} 
Perseroan Terbatas, serta akta lain yang dibuat oleh Notaris pada saat-saat tertentu. Notaris juga dituntut untuk dapat melakukan penemuan hukum dalan perjanjian atau kontrak tertentu karena ketidak sempurnaan hukum yang tersedia.

Notaris menghadapi masalah konkret yang diajukan oleh klien yang minta dibuatkan akta. Masalah hukum konkret atau peristiwa yang diajukan oleh klien merupak peristiwa konkret yang masih harus dipecahkan atau dirumuskan menjadi peristiwa hukum yang merupakan tugas notaris yang tidak selalu mudah. Peristiwa semacam ini notaries melakukan penemuan hukum. ${ }^{20}$

Notaris dalam melakukan proses penemuan hukum bersifat problematis yang artinya masalah-masalah yang diajukan oleh klien, dimana hasilnya merupakan hukum, sebab mempunyai kekuatan yang mengikat, akan tetapi belum dapat dikatakan sebagai sumber hukum, sebab belum ada satupun dalam teori yang mengemukakan tentang Notaris merupakan sumber hukum dalam menemukan hukum, walaupun Notaris melakukan penemuan hukum, klien yang mengajukan masalah hukum untuk menemukan hukumnya. ${ }^{21}$ Dengan demikian Notaris dalam rangka melakukan penemuan hukum dengan cara mengakomodasi kebutuhan klien mengenai kontrak atau perjanjian ataupun kesepakatan dari masalah yang dibawa. Notaris harus adil dan tidak boleh berat sebelah.

Jadi Notaris membuat penemuan hukum secara netral dan tidak memihak kepada siapapun. Hal ini dijelaskan di dalam Pasal 16 Undang-Undang Notaris, bahwa jabatan Notaris mengenai sikap netral yang harus ditempuh oleh seorang Notaris. Dengan posisi netral itu, Notaris diharapkan untuk memberikan penyuluhan hukum untuk dan atas tindakan hukum yang dilakukan Notaris atas permintaan kliennya.

Dengan demikian Notaris di samping hakim juga salah satu pihak dapat melakukan penemuan hukum berkaitan dengan pembuatan akta-akta yang menjadi tugasnya yang sudah diatur oleh Undang-Undang Jabatan Notaris, yakni UndangUndang Nomor 2 Tahun 2014 tentang Perubahan Atas Undang-Undang Nomor 3 Tahun 2004 tentang Jabatan Notaris, pembuatan akta-akta tersebut dimaksudkan untuk

\footnotetext{
20 Sudikno Mertokusumo, “Arti Penemuan Hukum Bagi Notaris”, http:// sudiknoartikel. blogspot.co.id/2012/12/arti-penemuan-hukum-bagi-notaris 1004.html, diakses 14/09/2015.

${ }^{21}$ Muhammad Yossi Shevtami, "Subyek Penemuan Hukum", http:// vossyfederer.blgspot.co.id/, diakses $11 / 09 / 2015$.
} 
membuat terobosan atau alternatif penyelesaian suatu kasus dengan cara lain sepanjang hal itu tidak melanggar hukum dan memenuhi asas kemanfaatan. ${ }^{22}$

Untuk melakukan penemuan hukum yang baik ilmu hukum dan perkembangan harus dikuasai dengan baik. Di samping itu sistem dan perkembangan hukum harus rajin diikuti. Apabila mau menegakkan hukum maka diharuskan bersikap jujur dan berani. Jujur tetapi tidak ada keberanian untuk mengambil tindakan tidak ada gunanya. Akan tetapi berani saja tidak dilandasi dengan kejujuran tidak akan membantu penegakan hukum. ${ }^{23}$

Ada dua unsur penting dalam penemuan hukum. Pertama, hukum/sumber hukum dan kedua adalah fakta. ${ }^{24}$ Pada permulaannya, unsur hukum/sumber hukum dalam penemuan hukum adalah undang-undang. Hal ini berkaitan dengan suatu postulat yang dikenal dengan istilah "De wet is onschendbaar" (undang-undang tidak dapat diganggu gugat) yang dalam hukum Belanda tercantum secara eksplisit dalam Pasal 120 Grondwet. Akan tetapi, dalam perkembangannya, tidak semua hukum ditemukan dalam undang-undang. ${ }^{25}$ Jadi unsur hukum/sumber hukum dalam penemuan hukum tidak hanya meliputi undang-undang semata, akan tetapi meliputi juga sumber hukum lainnya, yakni doktrin, yurisprudensi, perjanjian, dan kebiasaan.

Selanjutnya adalah fakta sebagai unsur penemuan hukum. Hal ihwal dalam penemuan hukum adalah penilaian terhadap fakta-fakta berdasarkan hukum. Sebelum hukum diterapkan pada peristiwa konkret, terlebih dahulu diharuskan menetapkan apa yang sesungguhnya menjadi situasi faktual sebagai penemuan suatu kebenaran, kemudian situasi faktual itu dapat dipandang sebagai relevan secara yuridis, seleksi dan kualifikasi atas fakta-fakta.

Sedangkan kesepakatan dari penemuan hukum yang Notaris lakukan itu yang akan menjadi penemuan hukum dan berlaku sebagai Undang-Undang bagi para pihak yang membuatnya, sebagaimana disebutkan di dalam Pasal 1338 Kitab Undang-Undang Hukum Perdata, bahwa semua perjanjian yang dibuat secara sah berlaku sebagai

\footnotetext{
${ }^{22}$ Mulyono, "Peran Penemuan Hukum Oleh Notaris Berkaitan Dengan Pembuatan Akta-Akta Penjualan Jaminan Kredit Macet Yang Dijamin Dengan Hak Tanggungan", http://mulyonotaris.blogspot.co.id/2014/ 06/peran-penemuan-hukum-oleh-notaris.html, diakses 11/09/2015.

23 Sudikno Mertokusumo, "Arti Penemuan Hukum Bagi Notaris", http:// sudiknoartikel.blogspot.co.id/ 2012/12/arti-penemuan-hukum-bagi-notaris 1004.html, diakses 14/09/2015.

${ }^{24}$ Eddy O.S. Hiariej, Asas Legalitas \& Penemuan Hukum dalam Hukum Pidana, Erlangga, Jakarta, 2009, hal. 56.

${ }^{25}$ J.A. Pontier, Op.Cit, hal. 18 dan 24.
} 
undang-undang bagi mereka yang membuatnya. ${ }^{26}$ Perjanjian berlaku sebagai undangundang bagi pihak-pihak, yakni perjanjian itu mempunyai kekuatan mmengikat dan memaksa serta memberi kepastian hukum kepada pihak-pihak yang membuatnya. Pihak-pihak harus mentaati perjanjian itu sama dengan mentaati undang-undang. Apabila ada pihak yang melanggar perjanjian yang mereka buat, maka dianggap sama dengan melanggar undang-undang, sehingga diberi akibat hukum tertentu, yaitu sanksi hukum. $^{27}$

\section{Kesimpulan}

Notaris merupakan suatu profesi dalam bidang hukum yang memberikan jasa hukum kepada masyarakat berupa akta sebagai alat bukti tertulis yang bersifat autentik tentang perbuatan, perjanjian, penetapan, dan peristiwa hukum yang diharuskan oleh peraturan perundang-undangan yang berlaku. Notaris dalam melakukan proses penemuan hukum bersifat problematis yang artinya masalah-masalah yang diajukan oleh klien, dimana hasilnya merupakan hukum, dan mengikat, akan tetapi belum dapat dikatakan sebagai sumber hukum, sebab belum ada satupun dalam teori yang mengemukakan tentang Notaris merupakan sumber hukum dalam menemukan hukum.

\section{Daftar Pustaka}

Abdulkadir Muhammad, Hukum Perdata Indonesia, Citra Aditya Bakti, Bandung, 1993.

Achmad Ali, Menguak Tabir Hukum (Suatu Kajian Filosofis dan Sosiologis), Gunung Agung, Jakarta, 2002.

Ahmad Rifai, Penemuan Hukum oleh Hakim Dalam Persfektif Hukum Progresif, Sinar Grafika, Jakarta, 2011.

Eddy O.S. Hiariej, Asas Legalitas \& Penemuan Hukum Dalam Hukum Pidana, Erlangga, Jakarta, 2009.

J.A. Pontier, Penemuan Hukum, Penerjemah B. Arief Shidarta, Jendela Mas Pustaka, Bandung, 2008.

John Z. Loudoe, Menemukan Hukum Melalui Tafsir Dan Fakta, Bina Aksara, Jakarta, 1985.

\footnotetext{
${ }^{26}$ R. Subekti, R. Tjitrosudibio, Kitab Undang-Undang Hukum Perdata, Pradnya Paramita, Jakarta, 1995, hal. 342 .

${ }^{27}$ Abdulkadir Muhammad, Hukum Perdata Indonesia, Citra Aditya Bakti, Bandung, 1993, hal. 234.
} 
Lawrence M. Friedman, Sistem Hukum Perspektif Ilmu Sosial, terj. oleh M. Khozim, cetakan keempat, Nusa Media, Bandung, 2011.

Marwan Mas, Pengantar Ilmu Hukum, Ghalia Indonesia, Jakarta, 2004.

Muhammad Yossi Shevtami, "Subyek Penemuan Hukum", http:// vossyfederer.blgspot.co.id/, diakses 11/09/2015.

Mulyono, "Peranan Penemuan hukum Oleh Notaris Berkaitan Dengan Pembuatan Akata-akta Penjualan Jaminan Kredit Macet Yang Dijamin Dengan Hak Tanggungan”, ｈttp://mulyonotaris.blogspot.co.id/2014/06/peran-penemuanhukum-oleh-notaris.html, diakses 11/09/2015.

Eddy O.S. Hiariej, Asas-Legalitas \& Penemuan Hukum Dalam Hukum Pidana, Erlangga, Jakarta, 2009.

R. Subekti \& R. Tjitrosudibio, Kitab Undang-Undang Hukum Perdata, Pradnya Paramita, Jakarta, 1995.

Satjipto Rahardjo, Penafsiran Hukum Yang Progresif dalam Anthon Freddy Susanto, Semiotika Hukum: Dari Dekonstruksi Teks Menuju Progresivitas Makna, Refika Aditama, Bandung, 2005.

Sudikno Mertokusumo, Mengenal Hukum Suatu Pengantar, Liberty, Yogyakarta, 1999. , Penemuan Hukum Sebuah Pengantar, Cahaya Atma Pustaka, Yogyakarta, 2014.

Sudikno Mertokusumo \& A. Pitlo, Bab-Bab Tentang Penemuan Hukum, Citra Aditya Bakti, Bandung, 2013.

, “Arti Penemuan Hukum Bagi Notaris", http://sudiknoartikel. blogspot.co.id/2012/12/arti-penemuan-hukum-bagi-notaris1004.html, diakses $14 / 09 / 2015$.

Undang-Undang Republik Indonesia Nomor 2 Tahun 2014 tentang Perubahan Atas Undang-undang Nomor 30 Tahun 2004 tentang Jabatan Notaris, Pustaka Mahardika, Yogyakarta.

Utrecht, Pengantar dalam Hukum Indonesia, Ichtiar, Jakarta, 1983.

Yudha Bhakti, "Penemuan Hukum Suatu Proses Memahami Ajaran Sumber Hukum", Pidato Purnabakti 70 Tahun, Fakultas Hukum Universitas Padjadjaran, Bandung, 2012. 